Article

\title{
Effects of Crude Fucus distichus Subspecies evanescens Fucoidan Extract on Retinal Pigment Epithelium Cells-Implications for Use in Age-Related Macular Degeneration
}

\author{
Kevin Rohwer ${ }^{1}$, Sandesh Neupane ${ }^{2}$, Kaya Saskia Bittkau ${ }^{2}$, Mayra Galarza Pérez ${ }^{2}$, \\ Philipp Dörschmann ${ }^{1}$, Johann Roider ${ }^{1}$, Susanne Alban ${ }^{2}$ and Alexa Klettner ${ }^{1, *}$ \\ 1 Department of Ophthalmology, University Medical Center, University of Kiel, 24105 Kiel, Germany; \\ k.rohwer@live.de (K.R.); Philipp.Doerschmann@uksh.de (P.D.); Johann.Roider@uksh.de (J.R.) \\ 2 Department of Pharmaceutical Biology, Pharmaceutical Institute, University of Kiel, 24105 Kiel, Germany; \\ sneupane@pharmazie.uni-kiel.de (S.N.); kbittkau@pharmazie.uni-kiel.de (K.S.B.); \\ mperez@pharmazie.uni-kiel.de (M.G.P.); salban@pharmazie.uni-kiel.de (S.A.) \\ * Correspondence: AlexaKarina.Klettner@uksh.de; Tel.: +49-431-500-24283
}

Received: 14 August 2019; Accepted: 10 September 2019; Published: 16 September 2019

check for updates

\begin{abstract}
Fucoidan extracts may have beneficial effects in age-related macular degeneration (AMD). Over-the-counter fucoidan preparations are generally undefined, crude extracts. In this study, we investigated the effect of a crude fucoidan extract from Fucus distichus subspecies evanescens (Fe) on the retinal pigment epithelium (RPE). Fe extract was investigated for chemical composition and molar mass. It was tested in primary RPE and RPE cell line ARPE19. Oxidative stress was induced with tert-butyl hydroperoxide, cell viability evaluated with MTT assay, VEGF secretion assessed in ELISA. Phagocytosis was evaluated in a fluorescence microscopic assay. Wound healing ability was tested in a scratch assay. Additionally, the inhibition of elastase and complement system by Fe extract was studied. The Fe extract contained about $61.9 \%$ fucose and high amounts of uronic acids $(26.2 \%)$. The sulfate content was not as high as expected (6.9\%). It was not toxic and not protective against oxidative stress. However, Fe extract was able to reduce VEGF secretion in ARPE19. Phagocytosis was also reduced. Concerning wound healing, a delay could be observed in higher concentrations. While some beneficial effects could be found, it seems to interfere with RPE function, which may reduce its beneficial effects in AMD treatment.
\end{abstract}

Keywords: Fucus distichus subsp. evanescens; fucoidan; retinal pigment epithelium; VEGF; oxidative stress; phagocytosis

\section{Introduction}

Fucoidans are sulfated polysaccharides derived from brown seaweed, consisting mainly of sulfated fucose. Many different biological activities have been described for fucoidan, but fucoidans are heterogeneous, varying strongly between different species [1].

Among the biological activities described for fucoidans are those interesting for potential treatment of age-related macular degeneration (AMD) [2]. AMD is the main cause for blindness and visual impairment in the elderly. Its pathogenesis is complex and multifactorial yet accepted as a major factor in the development of AMD is oxidative stress [3-5]. The retina is exposed to high degrees of oxidative stress through constant exposure to high-energetic sun light, due to a high activity of mitochondria in photoreceptors and retinal pigment epithelial cells (RPE), and due to the presence of oxidized fatty acids. The retinal pigment epithelium, a monolayer between the photoreceptors 
and the choroid, protects the retina from oxidative stress [6] but may succumb to the accumulating damage and degenerate later in life, leading to secondary degeneration of the photoreceptors $[4,7,8]$. In a subset of $\mathrm{AMD}$, the exudative or wet form, choroidal vessels may grow into the retina, trying to compensate for hypoxia that may be present in the retina due to poor oxygen supply. These vessels are highly immature and leak fluids into the subretinal space, destroying RPE cells and photoreceptors. The most important factor for this neovascularization is vascular endothelial growth factor (VEGF) and VEGF inhibition is the current treatment for exudative AMD [3,9].

Fucoidans have been shown to be protective against oxidative stress in various cell assays [10-13], and we have shown such a protective, anti-oxidative stress effect of fucoidan from Fucus vesiculosus in ocular cells as well [14]. Furthermore, a variety of fucoidans have been shown to inhibit VEGF and VEGF-mediated angiogenesis [15-17], including in our study on fucoidan of Fucus vesiculosus tested on endothelial cells stimulated with RPE supernatant [18]. However, the pro- or anti-angiogenic effect as well as its influence on VEGF are highly dependent on the origin, structure, and molecular weight of the fucoidan [19] and may exert different effects in different experimental systems [14].

Most studies have been carried out with commercially available fucoidan from Fucus vesiculosus. In this study, we have investigated a fucoidan extract from Fucus distichus subspecies evanescens. Previous studies on fucoidans from Fucus evanescens mainly focused on immunomodulating effects [20-22], while there have been only limited studies in the context of potential use for AMD [23].

Several studies have reported different structure and composition of fucoidan extracted from F. evanescens [20,24-27]. They described fucose as the main monosaccharide with a low amount of other sugars like mannose, glucose, galactose, and xylose. The diversity in their composition can be dependent on harvest time, place, and the applied extraction method [28].

In our study, we have used a crude extract from Fucus distichus subsp. evanescens harvested in the Kiel Fjord. The extract was chemically characterized, and some additional basic activities were determined to enable an estimation of its potencies compared to purified fucoidans and was investigated regarding its potential to protect against oxidative stress-induced cell death and to inhibit VEGF secretion. Furthermore, as a functional RPE is a prerogative for functional photoreceptors and needs to be protected to avoid the development of AMD, we additionally tested the effects of the extract on parameters of RPE functions, such as toxicity, phagocytosis, and wound healing.

\section{Results}

\subsection{Chemical Characterization of Fe Extract}

We determined the basic structural composition of Fe extract (Table 1). Its content of neutral monosaccharides showed to be very low $(7.54 \%)$, whereas the uronic acid content was quite high (26.1\%). The neutral monosaccharides were composed of fucose $(61.9 \%)$, xylose $(10.1 \%)$, mannose $(24.1 \%)$ and glucose $(3.9 \%)$. Additionally, the molecular weight $(\mathrm{Mw})(88.6 \pm 1.0 \mathrm{kDa})$, sulfate content $\left(\mathrm{SO}_{3} \mathrm{Na} ; 6.9 \%\right)$, protein content $(2.8 \%)$, and total phenolic content (TPC; $14.4 \pm 0.7 \mu \mathrm{g} \mathrm{GAE} / \mathrm{mg}$ ) were determined (Table 1).

Table 1. Structural composition of extract from Fucus distichus subsp. evanescens (Fe).

\begin{tabular}{|c|c|c|c|c|c|c|c|c|}
\hline \multicolumn{4}{|c|}{ Monosaccharide Composition (mol \%) } & Uronic Acid (\%) & Mw (kDa) & $\mathrm{SO}_{3} \mathrm{Na}(\%)$ & Protein $(\%)$ & $\begin{array}{c}\text { TPC } \\
(\mu \mathrm{g} \mathrm{GAE} / \mathrm{mg})\end{array}$ \\
\hline Fuc & $\mathrm{Xyl}$ & Man & Glc & \multirow{2}{*}{$26.1 \pm 0.2$} & \multirow{2}{*}{$88.60 \pm 1.0$} & \multirow{2}{*}{6.9} & \multirow{2}{*}{ 2. 8} & \multirow{2}{*}{$14.4 \pm 0.7$} \\
\hline 61.9 & 10.1 & 24.1 & 3.9 & & & & & \\
\hline
\end{tabular}

\subsection{Activity Assays}

Testing of the concentration-dependent inhibitory potency of $\mathrm{Fe}$ on elastase and complement system activation revealed half-maximal inhibitory concentrations $\left(\mathrm{IC}_{50}\right)$ of $1.48 \pm 0.08 \mu \mathrm{g} / \mathrm{mL}$ (elastase) and $5.73 \pm 1.11 \mu \mathrm{g} / \mathrm{mL}$ (complement system) (Table 2). The antioxidant capacity (AOC) of Fe extract 
$(500 \mu \mathrm{g} / \mathrm{mL})$ amounted to $4.65 \pm 1.80 \%$. However, compared to the reference compound Trolox, the effect was about 500 times weaker.

Table 2. Activities of Fe extract.

\begin{tabular}{ccc}
\hline Elastase Inhibition $\mathrm{IC}_{\mathbf{5 0}}(\boldsymbol{\mu \mathrm { g }} / \mathrm{mL})$ & Complement System Inhibition $\mathrm{IC}_{\mathbf{5 0}}(\boldsymbol{\mu g} / \mathrm{mL})$ & DPPH AOC $(\%)$ of $\mathbf{5 0 0 ~} \boldsymbol{\mu g} / \mathrm{mL}$ \\
\hline $1.48 \pm 0.08$ & $5.73 \pm 1.11$ & $4.65 \pm 1.80$ \\
\hline
\end{tabular}

\subsection{Toxicity of Fe}

We have tested a potential toxic effect of Fe extract on ARPE19 and primary RPE cells. For ARPE19, no influence of Fe extract in the tested concentrations $(1 \mu \mathrm{g} / \mathrm{mL}, 10 \mu \mathrm{g} / \mathrm{mL}, 100 \mu \mathrm{g} / \mathrm{mL}$ and $250 \mu \mathrm{g} / \mathrm{mL})$ was found after one day and three days of incubation. After seven days, a slight decrease of cell viability could be noted at a concentration of $100 \mu \mathrm{g} / \mathrm{mL}(95.60 \pm 3.43 \%)$, which reached statistical significance (Figure 1a-c). In primary RPE cells, no influence could be found after 1, 3 or 7 days (Figure 1d-f). In addition, even after four weeks of incubation or after use of $500 \mu \mathrm{g} / \mathrm{mL}$ Fe extract at any tested time point, no loss of cell viability could be seen (data not shown). Consequently, Fe extract does not impair the viability of RPE cells.
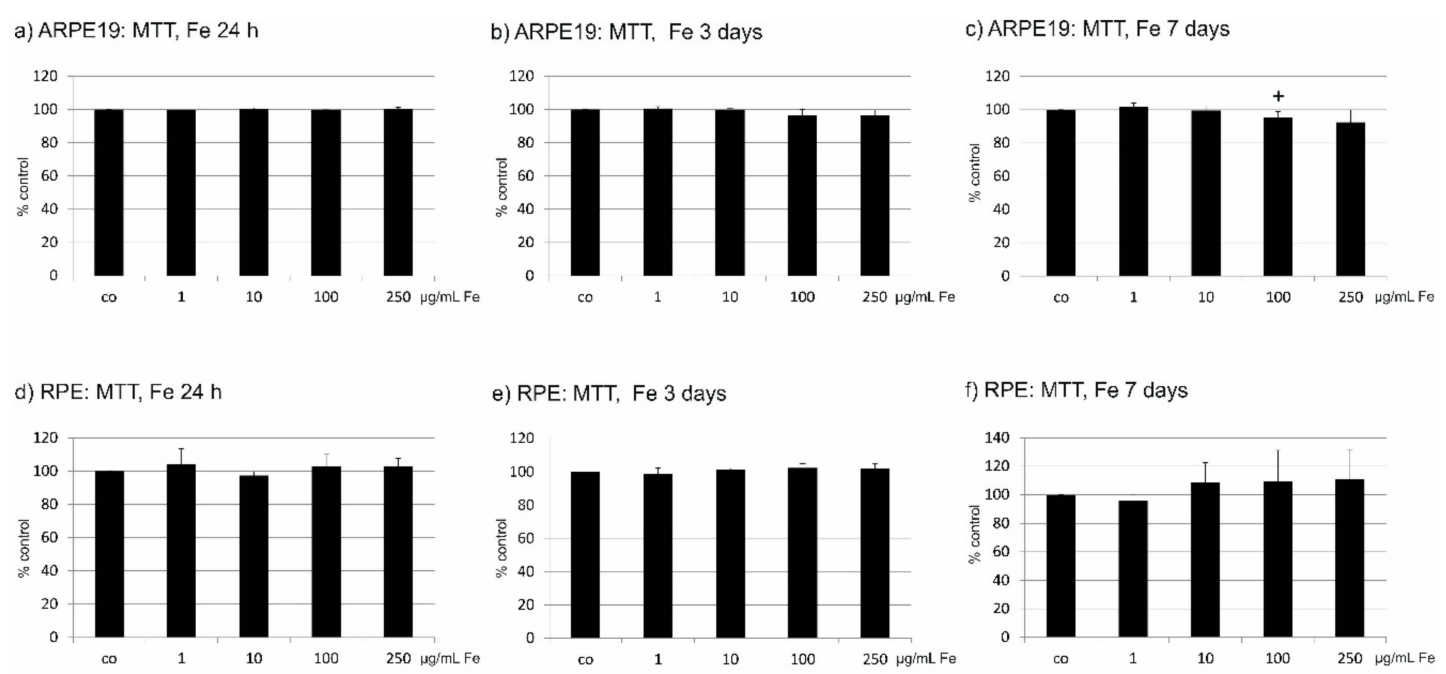

Figure 1. Cell viability tests after incubation with Fucus distichus subsp. evanescens fucoidan extract for $24 \mathrm{~h}$, three days or seven days. Cell viability was determined by MTT assay. In ARPE19 cells, no influence was found on cells after $24 \mathrm{~h}$ (a) or three days (b). After seven days, a slight but significant reduction of cell viability was seen at a concentration of $100 \mu \mathrm{g} / \mathrm{mL}$, but not at higher concentrations (c). In primary RPE cells, no influence on cell viability was seen after $24 \mathrm{~h}(\mathrm{~d})$, three days (e), or seven days (f). Significance was evaluated with student's $t$-test, ${ }^{+} p<0.05, \mathrm{co}=$ untreated control, $\mathrm{Fe}=$ crude fucoidan from Fucus distichus subsp. evanescens, $\mathrm{h}=$ hour.

\subsection{Oxidative Stress Protection}

Oxidative stress protection has been attributed to fucoidan and to polyphenols, found in crude fucoidan extracts. We tested the protective effect of Fe extract on ARPE19 cells treated with 500, 750, and $1000 \mu \mathrm{M}$ tert-butyl hydroperoxide (TBHP). All three concentrations of TBHP significantly reduced cell viability in ARPE19 cells. When treated with Fe extract $(1 \mu \mathrm{g} / \mathrm{mL}, 10 \mu \mathrm{g} / \mathrm{mL}, 100 \mu \mathrm{g} / \mathrm{mL}$, and $250 \mu \mathrm{g} / \mathrm{mL}$ ), no increase in cell viability was found for any TBHP or Fe extract concentration tested (Figure 2a-c). Clearly, this extract does not provide protection against oxidative stress. 

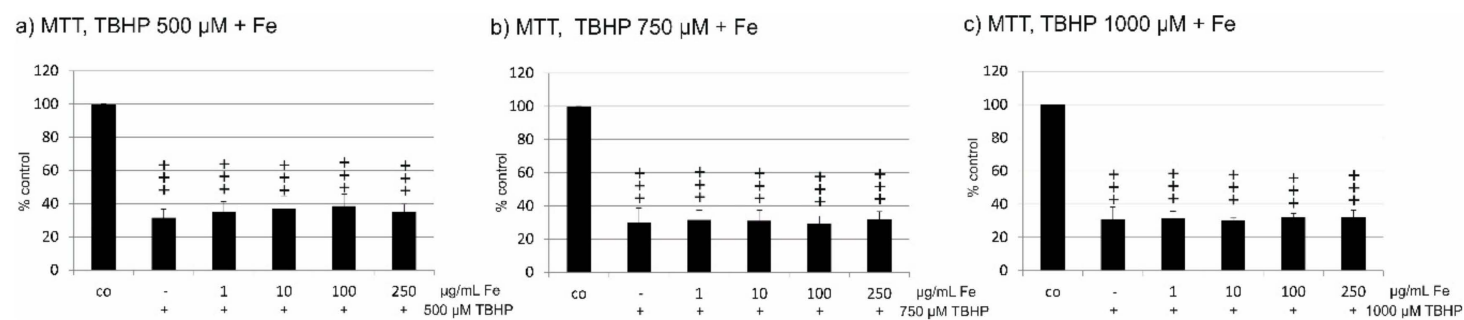

Figure 2. Cell viability after the induction of oxidative stress by tert-butylhydroperoxid (TBHP). Cell viability was determined by MTT assay. ARPE19 cells were incubated for $24 \mathrm{~h}$ with $500 \mu \mathrm{M}$ (a), $750 \mu \mathrm{M}(\mathbf{b})$, or $1000 \mu \mathrm{M}$ (c) TBHP and the protective effect of Fe extract was measured for 1, 10, 100, and $250 \mu \mathrm{M}$. No increase of cell viability was found for any concentration of Fe extract at any oxidative stimulus tested. Significance was evaluated with student's $t$-test, ${ }^{+++} p<0.001$ against untreated control, $\mathrm{co}=$ untreated control, $\mathrm{Fe}=$ crude fucoidan from Fucus distichus subsp. evanescens.

\subsection{VEGF Secretion}

VEGF secretion was detected in ARPE19 cells after incubation with the different concentrations of Fe extract $(1 \mu \mathrm{g} / \mathrm{mL}, 10 \mu \mathrm{g} / \mathrm{mL}, 100 \mu \mathrm{g} / \mathrm{mL}$ and $250 \mu \mathrm{g} / \mathrm{mL})$ after $24 \mathrm{~h}$, three days or seven days (Figure 3). At all time points, Fe extract reduced the VEGF concentration in the supernatants compared to untreated control, with the most profound effect after $24 \mathrm{~h}$, which reached statistical significance at concentrations of 100 and $250 \mu \mathrm{g} / \mathrm{mL}$ Fe extract $(100 \mu \mathrm{g} / \mathrm{mL}: 54.87 \pm 7.12 \%, p<0.001 ; 250 \mu \mathrm{g} / \mathrm{mL}$ $28.87 \pm 18.50 \%, p<0.001$ ) (Figure 3a). After three days, a significant reduction could be found at a concentration of $100 \mu \mathrm{g} / \mathrm{mL}(81.23 \pm 13.48 \%, p<0.05)$. Of note, 1 and $10 \mu \mathrm{g} / \mathrm{mL}$ resulted in a slight but significant increase of VEGF $(1 \mu \mathrm{g} / \mathrm{mL} 113.61 \pm 9.91 \%, p<0.05 ; 10 \mu \mathrm{g} / \mathrm{mL} 113.97 \pm 9.00 \%, p<0.05)$ (Figure 3b). After seven days, a significant decrease of the VEGF content could be found for $250 \mu \mathrm{g} / \mathrm{mL}$ $(67.00 \pm 12.32, p<0.01)$ (Figure 3c).
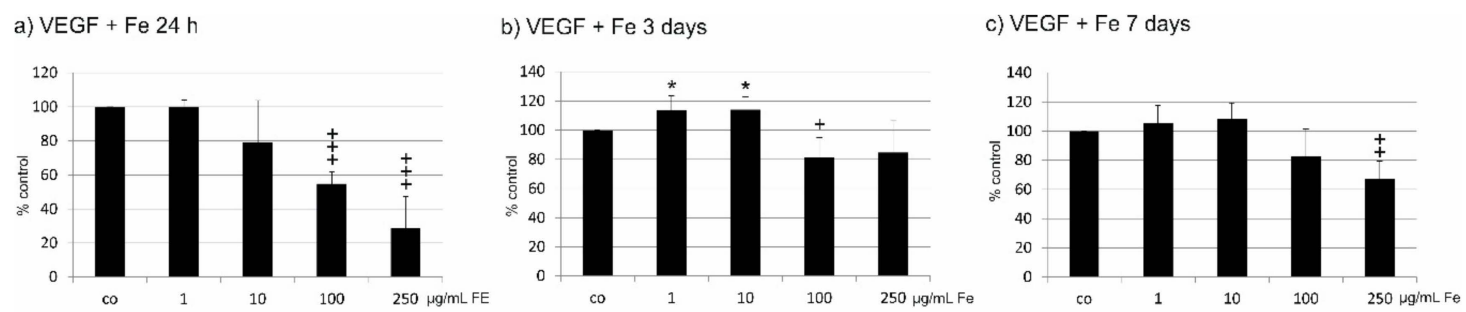

Figure 3. Effect of Fe extract on VEGF secretion of ARPE19 cells. VEGF content in the cell supernatant was investigated with a commercial ELISA. Fucus distichus subsp. evanescens fucoidan extract was tested in various concentrations $(1 \mu \mathrm{g} / \mathrm{mL}, 10 \mu \mathrm{g} / \mathrm{mL}, 100 \mu \mathrm{g} / \mathrm{mL}, 250 \mu \mathrm{g} / \mathrm{mL})$ for $24 \mathrm{~h}(\mathbf{a})$, three days (b), or seven days (c) on ARPE19 cells. After $24 \mathrm{~h}$ (a), a significant reduction of VEGF could be found for 100 and $250 \mu \mathrm{g} / \mathrm{mL}$. After three days (b), $100 \mu \mathrm{g} / \mathrm{mL}$ was still significantly effective. Of note, a slight but significant increase of VEGF secretion could be found for 1 and $10 \mu \mathrm{g} / \mathrm{mL}$ after three days. After seven days (c), $250 \mu \mathrm{g} / \mathrm{mL}$ significantly reduced VEGF content. Significance was evaluated with student's $t$-test against untreated control, ${ }^{+} p<0.05,{ }^{++} p<0.01,{ }^{++} p<0.001$, reduction against untreated control, ${ }^{*} p<0.05$, increase against untreated control, $\mathrm{co}=$ untreated control, $\mathrm{Fe}=$ crude fucoidan from Fucus distichus subsp. evanescens, $\mathrm{h}=$ hour.

\subsection{Phagocytosis}

Phagocytosis of shed photoreceptor outer segments is an important task of RPE cells. After incubation with Fe extract for $24 \mathrm{~h}, 1 \mu \mathrm{g} / \mathrm{mL}$ Fe extract significantly enhanced phagocytic activity $(1 \mu \mathrm{g} / \mathrm{mL} 139.92 \pm 68.32 \%, p<0.05)$, while 100 and $250 \mu \mathrm{g} / \mathrm{mL}$ significantly decreased it compared to untreated control $(100 \mu \mathrm{g} / \mathrm{mL} 41.00 \pm 30.75 \%, p<0.001 ; 250 \mu \mathrm{g} / \mathrm{mL} 24.77 \pm 19.94 \%, p<0.001)$ (Figure 4a). After three days, all concentrations tested significantly decreased phagocytic activity compared to untreated control $(1 \mu \mathrm{g} / \mathrm{mL} 56.42 \pm 40.34 \% ; 10 \mu \mathrm{g} / \mathrm{mL} 45.29 \pm 24.05 \% ; 100 \mu \mathrm{g} / \mathrm{mL}$ 
$16.07 \pm 9.39 \% ; 250 \mu \mathrm{g} / \mathrm{mL} 21.56 \pm 20.02 \%$; all $p<0.001$ ) (Figure $4 \mathrm{~b}$ ). After seven days of Fe extract incubation, a significant reduction of phagocytosis compared to untreated cells was seen at $100 \mu \mathrm{g} / \mathrm{mL}$ (33.97 $\pm 17.35 \% ; p<0.001)$ and $250 \mu \mathrm{g} / \mathrm{mL}(40.82 \pm 34.74 \% ; p<0.001)$ (Figure $4 \mathrm{c})$.
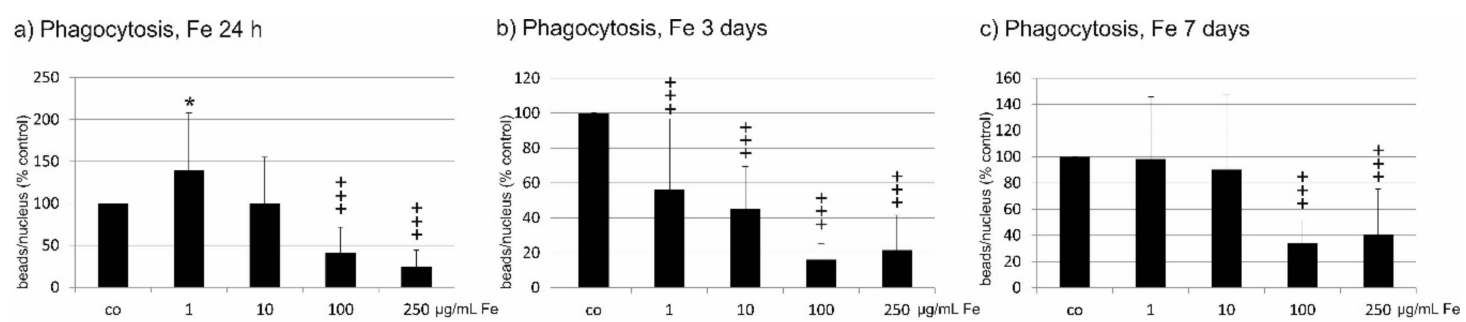

Figure 4. Phagocytic activity of RPE cells after incubation with Fucus distichus subsp. evanescens fucoidan extract. Phagocytic activity was investigated with a phagocytosis assay using photoreceptor outer segment-treated fluorescent latex beads. RPE cells were treated for $24 \mathrm{~h}(\mathbf{a})$, three days $(\mathbf{b})$, or seven days (c) with different concentrations of Fe extract $(1 \mu \mathrm{g} / \mathrm{mL}, 10 \mu \mathrm{g} / \mathrm{mL}, 100 \mu \mathrm{g} / \mathrm{mL}, 250 \mu \mathrm{g} / \mathrm{mL})$. After $24 \mathrm{~h}, 1 \mu \mathrm{g} / \mathrm{mL}$ induced a significant increase in phagocytic activity, while 100 and $250 \mu \mathrm{g} / \mathrm{mL}$ significantly reduced phagocytosis. After three days, all tested concentrations significantly reduced phagocytosis. After seven days, phagocytosis was significantly reduced by 100 and $250 \mu \mathrm{g} / \mathrm{mL}$. Significance was evaluated with student's $t$-test against untreated control, ${ }^{++} p<0.001$, reduction against untreated control, ${ }^{*} p<0.05$, increase against untreated control. co $=$ untreated control, $\mathrm{Fe}=$ crude fucoidan from Fucus distichus subsp. evanescens, $\mathrm{h}=$ hour.

\subsection{Wound Healing}

In the scratch assay, the wound area was analyzed 24 and $48 \mathrm{~h}$ post scratch of a confluent cell layer of RPE after treatment for $24 \mathrm{~h}$, four days, or seven days with Fe extract. Incubation with Fe extract for $24 \mathrm{~h}$ significantly slowed down wound healing measured $24 \mathrm{~h}$ after scratch at 100 and $250 \mu \mathrm{g} / \mathrm{mL} \mathrm{Fe}$ extract (control: $71.17 \pm 7.16 \% ; 100 \mu \mathrm{g} / \mathrm{mL} 80.31 \pm 3.67 \% ; 250 \mu \mathrm{g} / \mathrm{mL} 83.62 \pm 3.18 \%$; (both $p<0.001$ ). At $48 \mathrm{~h}$ after scratch, also $10 \mu \mathrm{g} / \mathrm{mL}$ as well as $100 \mu \mathrm{g} / \mathrm{mL}$ and $250 \mu \mathrm{g} / \mathrm{mL}$ significantly delayed wound healing (co 58.89 $\pm 11.54 \%, 10 \mu \mathrm{g} / \mathrm{mL} 67.41 \pm 4.30, p<0.01 ; 100 \mu \mathrm{g} / \mathrm{mL} 68.12 \pm 4.49, p<0.01 ; 250 \mu \mathrm{g} / \mathrm{mL}$ $70.81 \pm 6.24 \%, p<0.001$ ) (Figure 5a). After four days of incubation with Fe, wound healing $24 \mathrm{~h}$ post scratch was significantly delayed at concentrations of $10 \mu \mathrm{g} / \mathrm{mL}$ (co $65.01 \pm 13.34 \% ; 10 \mu \mathrm{g} / \mathrm{mL}$ $80.74 \pm 12.42 \%, p<0.01), 100 \mu \mathrm{g} / \mathrm{mL}(79.70 \pm 9.03 \% ; p<0.001)$, and $250 \mu \mathrm{g} / \mathrm{mL}(89.05 \pm 11.31 \% ; p<0.001)$ compared to scratched control not treated with Fe extract. But at $48 \mathrm{~h}$ after scratch, only $250 \mathrm{mg} / \mathrm{mL}$ displayed a significant delay of wound healing (co $61.60 \pm 15.69 \% ; 250 \mu \mathrm{g} / \mathrm{mL} 76.88 \pm 20.12 \%, p<0.05$ ) (Figure $5 \mathrm{~b}$ ). Long-term incubation with Fe extract for seven days $24 \mathrm{~h}$ post-scratch showed a significant delay in wound healing again for $100 \mu \mathrm{g} / \mathrm{mL}$ (co $72.91 \pm 9.46 \% ; 100 \mu \mathrm{g} / \mathrm{mL} 81.94 \pm 9.41 \%, p<0.01$ ) and $250 \mu \mathrm{g} / \mathrm{mL}(81.34 \pm 9.71 \%, p<0.05)$. After 48 hours, however, this effect was lost and conversely, wound healing was accelerated by $10 \mu \mathrm{g} / \mathrm{mL}$ Fe extract (co $69.54 \pm 8.15 \% ; 10 \mu \mathrm{g} / \mathrm{mL} 51.93 \pm 16.29 \%$, $p<0.001$ ) (Figure 5c). 

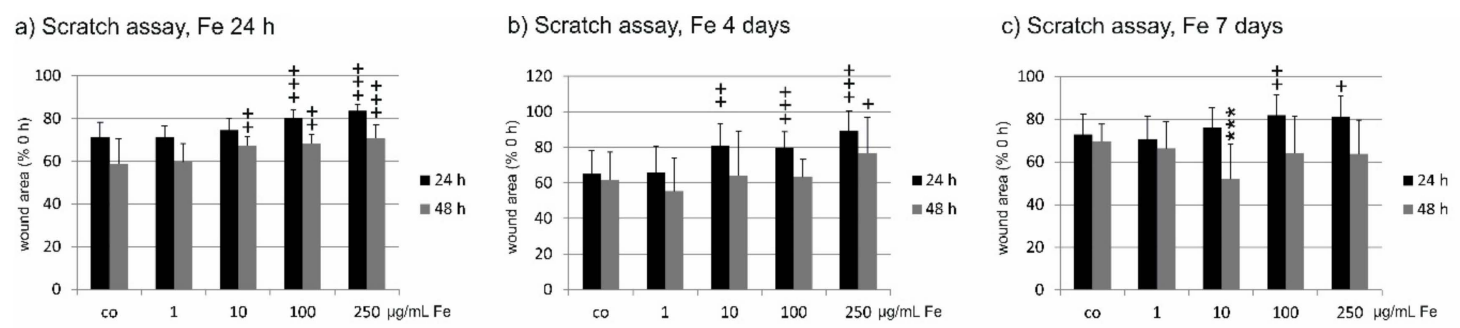

Figure 5. Wound healing of primary RPE cells after incubation with Fucus distichus subsp. evanescens fucoidan extract. A scratch was applied to a confluent RPE cell layer and the wound area was assessed 24 and $48 \mathrm{~h}$ after application. Cells were incubated for $24 \mathrm{~h}(\mathbf{a})$, four days (b), or seven days (c) with different concentrations of Fe extract $(1 \mu \mathrm{g} / \mathrm{mL}, 10 \mu \mathrm{g} / \mathrm{mL}, 100 \mu \mathrm{g} / \mathrm{mL}, 250 \mu \mathrm{g} / \mathrm{mL}$ ). (a) When cells were treated for $24 \mathrm{~h}$ with Fe extract, wound healing was significantly delayed one day after scratch at 100 and $250 \mu \mathrm{g} / \mathrm{mL}$. After $48 \mathrm{~h}$, wound healing was significantly delayed at 10, 100 and $250 \mu \mathrm{g} / \mathrm{mL}$. When cells were treated for four days with Fe extract (b), wound healing was significantly delayed one day after scratch at 10,100, and $250 \mu \mathrm{g} / \mathrm{mL}$. Forty-eight hours after scratch, a significant delay could be seen at $250 \mu \mathrm{g} / \mathrm{mL}$. After seven days of Fe extract incubation (c) and $24 \mathrm{~h}$ after scratch, wound healing was significantly delayed at 100 and $250 \mu \mathrm{g} / \mathrm{mL}$. This effect was lost $48 \mathrm{~h}$ after scratch, where $10 \mu \mathrm{g} / \mathrm{mL}$ significantly accelerated wound healing. Significance was evaluated with student's $t$-test against untreated control, ${ }^{+} p<0.05,{ }^{++} p<0.01,{ }^{+++} p<0.001$, delayed wound healing; ${ }^{* * *} p<0.001$, accelerated wound healing, $\mathrm{co}=$ scratched control with Fe treatment, $\mathrm{Fe}=$ crude fucoidan from Fucus distichus subsp. evanescens, $\mathrm{h}=$ hour.

\section{Discussion}

Potential use of fucoidans in medical application has raised much interest [29]. However, the effects of fucoidans may not only differ in dependence on the algae species but also due to the used extraction methods and different degrees of purity [1]. Often, commercially available cosmetics and food supplements are declared to contain fucoidans, but these are generally poorly defined, with considerable deviation in fucoidan content. So far, much research has been done with commercially available fucoidan from Fucus vesiculosus [30], including our own study on Fucus vesiculosus fucoidan for potential use in AMD or uveal melanoma [14,18]. In the present study, we have investigated a fucoidan from another alga, Fucus distichus subsp. evanescens, which has so far not received as much attention in the literature. Recently, quite pure fucoidan from Fucus distichus subsp. evanescens (Fuc-Fe) showed to reduce the VEGF secretion in ARPE19 and displayed high affinity to VEGF but had no protective effect on ARPE19 [23]. In the current study, we used a crude extract of this alga, which can be easily produced in high amounts, elucidating its efficacy.

Despite of the high content of fucose $(61 \%)$ in the Fe extract, which is the main monosaccharide of fucoidans, the low yield of neutral monosaccharides in the GLC analysis indicate that the content of fucoidan in the Fe extract is quite low. Accordingly, the sulfate content $\left(6.9 \%\right.$ as $\left.\mathrm{SO}_{3} \mathrm{Na}\right)$ was also quite low compared to $15-46 \%$ found in crude as well as purified fucoidans from Fucus distichus subsp. evanescens [20,25-27]. This suggests that Fe extract contains far less than $25 \%$ fucoidan, whereas the high uronic acid content $(26 \%)$ indicates a high content of alginic acid, another typical cell wall compound of brown algae. This had to be expected, since methods to remove alginic acid from the extract such as a precipitation with calcium were not applied for the production of Fe extract. As previously shown, the antioxidative capacity of fucoidans is mainly due to co-extracted polyphenols $[28,31]$. The Fe extract exhibited only weak radical scavenging potency, which was comparable with that of Fuc-Fe and correlated with the respective total phenolic content, which turned out to be lower than that of fucoidan from Fucus vesiculosus (manuscript submitted). This is in line with the missing oxidative stress protection of Fe extract (see below).

Regarding a potential use of fucoidan from brown algae as a treatment option for age-related macular degeneration, we tested its effect against oxidative stress, as this comprises a general 
pathological pathway in AMD, and its interaction with VEGF, as this is the major pathological factor for exudative AMD.

Fe extract did not exhibit any protection against oxidative-stress induced loss of cell viability in ARPE19 cells. This is in contrast to our finding for fucoidan from Fucus vesiculosus, which protected the uveal melanoma from oxidative stress-induced cell death [14], and in correspondence with a paper recently published by our group, which showed a protection by Fuc-Fe of against oxidative stress in uveal melanoma cells but not in ARPE19 [23]. Obviously, different cell types react differently to oxidative stress. Uveal melanoma cell lines are rather susceptible to oxidative stress, as their superoxide dismutase (SOD) activity, which acts in oxidative stress protection, tends to be reduced [32], while RPE are highly resistant to oxidative stress, which is mainly mediated by Nrf-2 [6,33]. Fucoidan has been reported to confer its protection by activation of Nrf-2 and upregulation of SOD [12,13,34], and it is conceivable that this protective pathway may work on one cell line with reduced SOD activity (uveal melanoma) but not with a cell line with constitutive Nrf-2 activation (RPE). However, the lack of any effect concerning oxidative-stress induced cell death strongly indicates that we find no scavenging effect for this Fe extract. These data on oxidative stress protection confirm our previous findings that fucoidan from species other than Fucus distichus subsp. evanescens may be more suitable for oxidative stress protection [23] but also that the presence of additional compounds in a crude extract does not hold any beneficial effects considering oxidative stress protection.

Concerning VEGF inhibition, Fe extract turned out to reduce VEGF secretion. However, this effect was time- and concentration-dependent, showing the strongest effect after one day. Of note, however, we found an induction of VEGF secretion after three days for lower concentrations of fucoidan ( 1 and $10 \mu \mathrm{g} / \mathrm{mL}$ ), which is not desirable, as the VEGF content in (exudative) AMD eyes has to be reduced. Compared with our data obtained with fucoidan from commercially available Fucus vesiculosus and with the purer Fuc-Fe $[18,23]$, our data indicate that Fe extract is less suitable for VEGF secretion inhibition. As this is a crude extract, our data also suggest that no benefit can be seen from additional compounds other than fucoidan present in the extract. Furthermore, fucoidans from other species such as Saccharina latissima or Fucus vesiculosus may be more promising for further development [23].

RPE cells have a plethora of function in the retina and their functions are vital for a healthy, functioning retina [35]. Furthermore, RPE cells in AMD patients are already challenged and in danger of degeneration. Therefore, any substance to be considered for use in AMD should interfere as little with RPE function as possible. We have tested toxicity, wound healing and phagocytosis as parameters. Similar to our findings with Fucus vesiculosus fucoidan as well as fucoidans from five other algae [36], we did not find a relevant toxic effect. However, some minor but nevertheless significant reduction was seen after seven days, which was not observed for Fucus vesiculosus fucoidan [18]. Notably, both Fucus vesiculosus and Fe extract reduced the wound healing abilities of RPE cells. However, the data obtained 24 and 48 hours after scratch suggest that this is a transient effect and might therefore not be of further consequence for RPE cell function. More importantly, considering the function of RPE cells, Fe extract reduced phagocytic activity of the cells at all tested time points at 100 and $250 \mu \mathrm{g} / \mathrm{mL}$ (and additionally at 1 and $10 \mu \mathrm{g} / \mathrm{mL}$ after three days). A previous study testing fucoidan of Fucus vesiculosus at a concentration of $100 \mu \mathrm{g} / \mathrm{mL}$ did not exhibit a reduction of phagocytic activity [18]. In that study, phagocytosis was evaluated only after short term incubation, therefore the effect could be related to duration of fucoidan exposition. However, the effect of the Fe extract was found at every time point tested, indicating a species-dependent effect. In addition, it is possible that other components present in the extract are interfering with phagocytic activity. As a prolonged reduction of phagocytosis could possibly impair the function of the retina, which is not desirable when treating AMD, further testing is needed to elucidate the effects of purity and species of fucoidans on RPE function.

The results so far indicate some beneficial effects of this crude extract of Fucus distichus subsp. evanescens with regard to AMD, concerning VEGF inhibition. Previous investigations with the purer Fuc-Fe suggest that beneficial effects are due to the fucoidan content and not due to other compounds of the Fe extract. The reduction of phagocytic activity in RPE cells may be of concern. 
There are other aspects of interest for AMD pathology that we did not test in our assays, such as lipid metabolism $[37,38]$, which may be influenced by fucoidans $[39,40]$, or inflammatory aspects [41], which also could be influenced by fucoidans and especially by fucoidan of Fucus distichus subsp. evanescens [22,42]. Future studies should address these issues, but for these, highly purified fucoidans should be used. In conclusion, crude extracts from Fucus distichus subsp. evanescens are of some interests in regard to potential AMD treatment considering their effect on RPE cells. However, fucoidans of other species may be of higher interest, and, importantly, further studies should be performed with highly purified fucoidans.

\section{Materials and Methods}

\subsection{Extraction}

Fucus distichus subsp. evanescens was cleaned from epiphytes and washed with tap water, drained and autoclaved. The material was mixed with four volumes of extraction buffer (100 $\mathrm{mM}$ Tris base, $\mathrm{pH}$ 10.0) and shredded and blended with Ultraturrax (Sigma-Aldrich, Steinheim, Germany) for $1 \mathrm{~min}$ at maximum speed. After centrifugation and separation of the supernatant, the algae material was two further times treated as described with one volume of extraction buffer each. Then, $\mathrm{NaCl}$ and citric acid were added to the combined supernatants resulting in $600 \mathrm{mM} \mathrm{NaCl}$ and $\mathrm{pH} 4.75$. The extract was then mixed with ethanol (final concentration 50\%) (v/v) for precipitation over night at room temperature. After centrifugation, the pellet was dissolved in $20 \mathrm{mM} \mathrm{NaOH}$, and the precipitation procedure including the addition of $\mathrm{NaCl}$ and citric acid was repeated once, and was finally dissolved in pure water ( $\mathrm{pH} \sim 6.0$ ), frozen, and lyophilized. The yield amounted to about $4 \%$ in relation to wet algae mass and to $18.4 \%$ in dry algae mass.

\subsection{Elemental Analysis}

The contents of hydrogen, carbon, nitrogen, and sulfur in the crude Fucus distichus subsp. evanescens fucoidan extract $(\mathrm{Fe})$ were determined by elemental analysis performed with the HEKAtech CHNS Analyser (HEKAtech, Wegberg, Germany; calibrator: sulfanil amide). After gas liquid chromatographic separation (carrier gas: helium), the respective analyte gases were detected in a thermal conductivity detector. The nitrogen content (\%) was multiplied by 6.25 to estimate the protein content [43]. Based on the sulfur content $(\%)$, the content of sulfate groups (as $-\mathrm{SO}_{3} \mathrm{Na}$ ) was calculated.

\subsection{Molecular Weight (Mw) Determination}

The average molecular weight $(\mathrm{Mw})$ of the fucoidan extract was examined by size exclusion chromatography (SEC) (ÄKTA Pure 25 from GE Healthcare, Munich, Germany), coupled with online multi-angle light scattering (MALS) and refractive index (RI) detection using DAWN 8+ and Optilab T-rex (Wyatt Technology Corporation, Dernbach, Germany). For the separation by hydrodynamic volume, an OHPak LB-806M 8.0 mmID X 300 mmL (ShodexTM, Munich, Germany) column was used. The mobile phase was composed of $0.15 \mathrm{~mol} / \mathrm{L} \mathrm{NaCl}, 0.025 \mathrm{~mol} / \mathrm{L} \mathrm{NaH}_{2} \mathrm{PO}_{4}, 0.025 \mathrm{~mol} / \mathrm{L} \mathrm{Na}_{2} \mathrm{HPO}_{4}$ ( $\mathrm{pH}$ 7.0) and a flow rate of $0.5 \mathrm{~mL} / \mathrm{min}$ was applied. The sample was dissolved in the elution buffer to a concentration of $2.0 \mathrm{mg} / \mathrm{mL}$, and $100 \mu \mathrm{L}$ were injected. The elution buffer was degassed using ultrasound for $30 \mathrm{~min}$. The MALS detector was calibrated by the manufacturer using toluol. The used refractive index increment $(\mathrm{dn} / \mathrm{dc})$ was $0.150 \mathrm{~mL} / \mathrm{g}$. The $\mathrm{Mw}$ values were calculated with ASTRA 7.1.2.5 (Wyatt Technology Corporation, Dernbach, Germany). The chromatographic system was controlled by UNICORN 7.2 GE (Healthcare, Munich, Germany).

\subsection{Monosaccharide Composition by Acetylation Analysis}

For the determination of neutral monosaccharide composition, the Fe extract was hydrolyzed with $2.0 \mathrm{~mol} / \mathrm{L}$ trifluoroacetic acid (TFA) at $121^{\circ} \mathrm{C}$ [44] and, after evaporation of TFA, converted into alditol acetate derivatives (AA) by reduction and acetylation [45]. The AA were separated by gas liquid 
chromatography (GLC) on an OPTIMA-225-0.25 $\mu \mathrm{m}$ fused silica capillary column $(25 \mathrm{~m} \times 0.25 \mathrm{~mm}$ i.d., film thickness $0.25 \mu \mathrm{m}$, Macherey-Nagel, Düren, Germany) using an GC 7890B gas chromatograph (Agilent Technologies, Waldbronn, Germanywith integrated flame ionization detector. The helium flow rate was $1.0 \mathrm{~mL} / \mathrm{min}$, the oven temperature was $180^{\circ} \mathrm{C}$ for $5 \mathrm{~min}$ followed by an increase of $1{ }^{\circ} \mathrm{C} / \mathrm{min}$ up to $210^{\circ} \mathrm{C}$ held for $10 \mathrm{~min}$, the temperatures of injector and detector were $250^{\circ} \mathrm{C}$ and $240{ }^{\circ} \mathrm{C}$, respectively. The AA were identified by their retention times. For quantitative analysis, the samples were supplemented with a defined amount of myo-inositol as an internal standard. The percentage of the respective AA was calculated by Agilent MassHunter Qualitative Analysis Workflows B.08.00, (Waldbronn, Germany).

\subsection{Uronic Acid Determination}

Uronic acids were quantified by reaction with 3-hydroxydiphenyl according to the method by Blumenkrantz and Asboe-Hansen modified by Filisetti-Cozzi and Carpita [46].

\subsection{Total Phenolic Content}

The total phenolic content (TPC) was determined by a modified Folin-Ciocalteu method in a microplate format [47] with slightly adapted volumes. Aqueous fucoidan extract $(20 \mu \mathrm{L})$ was mixed with 0.025 N Folin-Ciocalteu reagent (200 $\mu \mathrm{L}$; Merck Millipore, Cat. 109001) and incubated for $5 \mathrm{~min}$. Then, $2 \mathrm{M} \mathrm{Na}_{2} \mathrm{CO}_{3}(30 \mu \mathrm{L})$ was added and absorption was measured at $660 \mathrm{~nm}$ (FLUOstar Omega, BMG LABTECH GmbH, Ortenberg, Germany) after 2 h. Gallic acid (Roth, Cat. 7300.1) was used as reference and TPC of sample was expressed as gallic acid equivalents (GAE) in $\mu \mathrm{g}$ per mg of the dry substance.

\subsection{DPPH Scavenging Assay}

The antioxidant potency of the crude Fucus distichus subsp. evanescens fucoidan extract was determined by the 2,2-diphenyl-1-picrylhydrazyl radical (DPPH; Sigma-Aldrich, Munich, Germany, Cat. D9132) scavenging microplate assay as previously described [48]. An aliquot of $100 \mu \mathrm{L}$ of a $0.20 \mathrm{mmol} / \mathrm{L}$ DPPH-solution in ethanol $70 \%(\mathrm{~V} / \mathrm{V})$ was mixed with $100 \mu \mathrm{L}$ of the sample $(0.5 \mathrm{mg} / \mathrm{mL}$ in ethanol $70 \%(\mathrm{~V} / \mathrm{V})$ ). For the control, $100 \mu \mathrm{L}$ DPPH solution were mixed with $100 \mu \mathrm{L}$ ethanol $70 \%(\mathrm{~V} / \mathrm{V})$. After incubation for $30 \mathrm{~min}$ at $20^{\circ} \mathrm{C}$ in the dark, the absorption (A) was measured at $520 \mathrm{~nm}$ using the plate reader FLUOstar Omega (BMG LABTECH GmbH, Ortenberg, Germany). The radical scavenging potency of the fucoidan samples was calculated by the formula

$$
\text { radical scavenging potency }(\%)=(\text { A control }- \text { A sample }) / \text { A control } \times 100 \text {. }
$$

Trolox (6-hydroxy-2,5,7,8-tetramethylchroman-2-carboxylic acid; Sigma Aldrich, Munich, Germany) dissolved in ethanol $70 \%(\mathrm{~V} / \mathrm{V})$ was used as reference substance. Its concentration ranged from 3 to $12 \mu \mathrm{g} / \mathrm{mL}$.

\subsection{Fluorigenic PMN-Elastase Activity Assay}

The elastase inhibitory activity was examined by a fluorogenic microplate assay using elastase from human polymorph nuclear granulocytes (PMN, EC 3.4.21.37, Merck Millipore, Germany) and the substrate MeOSuc-Ala-Ala-Pro-Val-7-amido-4-methylcoumarin (Bachem, Bubendorf, Switzerland) as previously described $[49,50]$. By means of the concentration-dependent inhibition curves, the concentration of test compound for $50 \%$ inhibition of elastase activities $\left(\mathrm{IC}_{50} \mathrm{in} \mu \mathrm{g} / \mathrm{mL}\right)$ was calculated.

\subsection{Hemolytic Classical Complement Modulation Assay}

An aliquot of $75 \mu \mathrm{L}$ fucoidan extract in veronal buffered saline (VBS: 5,5-diethylbarbituric acid $4.94 \mathrm{mmol} / \mathrm{L}, \mathrm{NaCl} 145 \mathrm{mmol} / \mathrm{L}, \mathrm{MgCl}_{2} 0.83 \mathrm{mmol} / \mathrm{L}, \mathrm{CaCl}_{2} 0.25 \mathrm{mmol} / \mathrm{L}, \mathrm{pH} 7.3$ ) was mixed with $50 \mu \mathrm{L}$ of a hemolytic system consisting of sheep erythrocytes sensitized with rabbit antibodies (Labor 
Dr. Merk \& Kollegen, Ochsenhausen, Germany) in the well of a V-bottom microplate (nunc ${ }^{\mathrm{TM}} 249570$, Thermo Fisher Scientific, Germany). Then, $25 \mu \mathrm{L}$ of a $2.1 \%$ human pooled serum dilution in VBS were added. After incubation for $45 \mathrm{~min}$ at $37^{\circ} \mathrm{C}$ and subsequent centrifugation for $15 \mathrm{~min}$ at $952 \times \mathrm{g}$ at room temperature, $100 \mu \mathrm{L}$ of the supernatant was transferred into a well of a flat bottom microplate (nunc $^{\text {TM }}$ 269620, Thermo Fisher Scientific, Regensburg, Germany) and diluted with $100 \mu \mathrm{L}$ distilled water. The optical density was measured at $405 \mathrm{~nm}$. For control values, VBS instead of crude Fe extract and hemolytic system were mixed with $2.1 \%$ serum dilution (100\% hemolysis) and inactivated $2.1 \%$ serum dilution ( $0 \%$ hemolysis), respectively. By means of the concentration-dependent hemolysis curves, the $\mathrm{IC}_{50}(\mu \mathrm{g} / \mathrm{mL})$ was calculated.

\subsection{Cell Culture}

Primary porcine RPE cells were prepared and cultivated as previously described [51] with modifications [52]. In brief, eyes were obtained from a local slaughterhouse, cleaned, the anterior segment and retina were discarded, and RPE cells harvested by trypsin digestion. Cells were used in the first passage at confluence, morphology, and confluency observed in light microscopy. Cells were maintained in HyClone DMEM (GE Healthcare, Munich, Germany, supplemented with penicillin/streptomycin $(1 \%)$, HEPES $(2.5 \%)$, sodium pyruvate $(110 \mathrm{mg} / \mathrm{mL})$, and $10 \%$ fetal calf serum, Linaris $\mathrm{GmbH}$, Wertheim-Bettingen, Germany). The immortal RPE cell line ARPE19 was obtained from ATCC and cultivated in DMEM (Merck, Darmstadt, Germany), supplemented with penicillin/streptomycin (1\%), non-essential amino acids (1\%), and $10 \%$ fetal calf serum.

\subsection{Treatment with Fucus distichus subsp. evanescens extract (Fe)}

Fe extract was solved in Ampuwa water (Fresenius Kabi, Bad Homburg, Germany) in a concentration of $10 \mathrm{mg} / \mathrm{mL}$ and filtered through a $0.2 \mu \mathrm{m}$ filter. Cells were treated with 1,10 , 100 , and $250 \mu \mathrm{g} / \mathrm{mL}$ Fe extract for indicated time periods, diluted in cell culture medium. If stimulation time exceeded three days, medium (including Fe extract) was renewed twice a week.

\subsection{Oxidative Stress}

Oxidative stress was induced by tert-butyl hydroperoxide (TBHP), a stable inducer of oxidative stress in RPE cells, as previously described [33]. In this study, we used $500 \mu \mathrm{M}, 750 \mu \mathrm{M}$, and $1000 \mu \mathrm{M}$ TBHP for $24 \mathrm{~h}$ on ARPE19 cells. Cells were incubated with indicated concentration of Fe extract for $30 \mathrm{~min}$, then TBHP (500 $\mu \mathrm{M}, 750 \mu \mathrm{M}$, and $1000 \mu \mathrm{M}$, respectively) was added. After incubation for $24 \mathrm{~h}$, cell viability was tested using an MTT test as described below.

\subsection{Methyl Thiazolyl Tetrazolium (MTT) Assay}

MTT assay is an established viability assay [53] and was conducted as previously described [18]. In brief, cells were incubated with $0.5 \mathrm{mg} / \mathrm{mL}$ MTT (3-(4,5-dimethylthiazol-2-yl)-2,5-diphenyltetrazoliumbromid), solved in DMEM without phenol red, washed, and lysed in dimethyl sulfoxide (DMSO). Absorption was measured at $550 \mathrm{~nm}$ with a spectrometer (Elx800, BioTek, Bad Friedrichshall, Germany).

\subsection{VEGF ELISA}

ARPE19 supernatants were collected after $24 \mathrm{~h}$, three days and seven days, by quick centrifugation and stored at $-20^{\circ} \mathrm{C}$ until assessment. VEGF content of the supernatant of ARPE19 cells were determined using a commercially available ELISA kit (R\&D Systems), following the manufacturer's instructions. 


\subsection{Phagocytosis Assay}

Phagocytosis assay was conducted as previously described [54]. In brief, photoreceptor outer segments were prepared from porcine retina and used to opsonize fluorescence-labelled latex beads. Cells were incubated with Fe extract for indicated time periods and treated with opsonized latex beads for four hours. Uptake of beads was detected by fluorescence microscopy (Apotome, Zeiss Microscopy $\mathrm{GmbH}$, Jena, Germany) and evaluated in Axiovision software (Zeiss).

\subsection{Wound Healing Assay (Scratch Assay)}

Scratch assay was conducted as previously described [18]. In brief, a wound ("scratch") was applied to a confluent cell layer of primary RPE cells using a pipet tip. Photos were taken immediately after the wound application as well as 24 and $48 \mathrm{~h}$ later in light microscopy. Area of wound was assessed with Axiovision software. Wound healing is depicted as \% wound area in relation to wound area at time of scratch.

\subsection{Statistics}

Each experiment was independently repeated at least three times. Calculation of mean, standard deviation, and significance was conducted in Microsoft Excel. Significance was assessed with student's $t$-test. A $p$-value of 0.05 or below was considered significant.

\section{Conclusions}

In conclusion, crude extracts from Fucus distichus subsp. evanescens are of some interests in regard to potential AMD treatment considering their VEGF reducing effect on RPE cells. However, other fucoidans have shown more promising effects. Furthermore, the tested crude extracts interfere with RPE function, such as phagocytosis, which may be a cause of concern. Taken together, fucoidans of other species may be of higher interest, and, importantly, further studies should be performed with highly purified fucoidans.

Author Contributions: Conceptualization, A.K. and S.A.; methodology, A.K., K.S.B., K.R., P.D., M.G.P., and S.A.; S.N. validation, A.K., K.S.B., K.R., S.A., and S.N.; formal analysis, A.K., K.S.B., K.R., M.G.P.; P.D., S.A., and S.N.; investigation, K.R., K.S.B., M.G.P., and S.N.; resources, A.K., J.R., and S.A.; data curation, K.S.B., K.R., and S.N.; writing-original draft preparation, A.K. and S.A.; writing-review and editing, A.K., J.R., K.R., K.S.B., P.D., S.N., and S.A.; visualization, A.K. and K.R.; supervision, A.K., J.R., and S.A.; project administration, A.K.; funding acquisition, A.K.

Funding: This study has been conducted with funding of the Baltic Blue Biotechnology Alliance (InterReg5b) and with funding of the FucoSan Health from the Sea Project, supported by EU InterReg-Deutschland-Denmark and the European Fond of Regional Development.

Acknowledgments: We especially thank Coastal Research \& Management and Kiel, for the collection of the algae and Christoph Plieth, Center for Biochemistry and Molecular Biology, University of Kiel, for providing the extracts.

Conflicts of Interest: The authors declare no conflict of interest.

\section{References}

1. Li, B.; Lu, F.; Wei, X.; Zhao, R. Fucoidan: Structure and bioactivity. Molecules 2008, 13, 1671-1695. [CrossRef] [PubMed]

2. Klettner, A. Fucoidan as a potential therapeutic for major blinding dieases-A hypothesis. Mar. Drugs 2016, 14, 31. [CrossRef] [PubMed]

3. Miller, J.W. Age-related macular degeneration revisited-piecing the puzzle: The LXIX Edward Jackson memorial lecture. Am. J. Ophthalmol. 2013, 155, 1-35. [CrossRef]

4. Bellezza, I. Oxidative Stress in Age-Related Macular Degeneration: Nrf2 as Therapeutic Target. Front. Pharmacol. 2018, 9, 1280. [CrossRef] [PubMed]

5. Klettner, A. Age-related macular degeneration-Biology and treatment. Med. Monatsschr. Pharm. 2015, 38, 258-264. [PubMed] 
6. Klettner, A. Oxidative stress induced cellular signaling in RPE cells. Front. Biosci. 2012, 4, 392-411. [CrossRef]

7. Datta, S.; Cano, M.; Ebrahimi, K.; Wang, L.; Handa, J.T. The impact of oxidative stress and inflammation on RPE degeneration in non-neovascular AMD. Prog. Retin. Eye Res. 2017, 60, 201-218. [CrossRef] [PubMed]

8. Nowak, J.Z. Oxidative stress, polyunsaturated fatty acids-derived oxidation products and bisretinoids as potential inducers of CNS diseases: Focus on age-related macular degeneration. Pharmacol. Rep. 2013, 65, 288-304. [CrossRef]

9. Schmidt-Erfurth, U.; Chong, V.; Loewenstein, A.; Larsen, M.; Souied, E.; Schlingemann, R.; Eldem, B.; Monés, J.; Richard, G.; Bandello, F. European Society of Retina Specialists. Guidelines for the management of neovascular age-related macular degeneration by the European Society of Retina Specialists (EURETINA). Br. J. Ophthalmol. 2014, 98, 1144-1167. [CrossRef]

10. Kim, K.J.; Yoon, K.Y.; Lee, B.Y. Low molecular weight fucoidan from the sporophyll of Undaria pinnatifida suppresses inflammation by promoting the inhibition of mitogen-activated protein kinases and oxidative stress in RAW264.7 cells. Fitoterapia 2012, 83, 1628-1635. [CrossRef]

11. Kim, E.A.; Lee, S.H.; Ko, C.I.; Cha, S.H.; Kang, M.C.; Kang, S.M.; Ko, S.C.; Lee, W.W.; Ko, J.Y.; Lee, J.H.; et al. Protective effect of fucoidan against AAPH-induced oxidative stress in zebrafish model. Carbohydr. Polym. 2014, 102, 185-191. [CrossRef] [PubMed]

12. Ryu, M.J.; Chung, H.S. Fucoidan reduces oxidative stress by regulating the gene expression of HO-1 and SOD-1 through the Nrf2/ERK signaling pathway in HaCaT cells. Mol. Med. Rep. 2016, 14, 3255-3260. [CrossRef] [PubMed]

13. Wang, Y.Q.; Wei, J.G.; Tu, M.J.; Gu, J.G.; Zhang, W. Fucoidan Alleviates Acetaminophen-Induced Hepatotoxicity via Oxidative Stress Inhibition and Nrf2 Translocation. Int. J. Mol. Sci. 2018, 19, 4050. [CrossRef] [PubMed]

14. Dithmer, M.; Kirsch, A.M.; Richert, E.; Fuchs, S.; Wang, F.; Schmidt, H.; Coupland, S.E.; Roider, J.; Klettner, A. Fucoidan does not exert anti-tumorigenic effects on uveal melanoma cell lines. Mar. Drugs 2017, 15, 193. [CrossRef] [PubMed]

15. Koyanagi, S.; Tanigawa, N.; Nakagawa, H.; Soeda, S.; Shimeno, H. Oversulfation of fucoidan enhances its anti-angiogenic and antitumor activities. Biochem. Pharmacol. 2003, 65, 173-179. [CrossRef]

16. Chen, H.; Cong, Q.; Du, Z.; Liao, W.; Zhang, L.; Yao, Y.; Ding, K. Sulfated fucoidan FP08S2 inhibits lung cancer cell growth in vivo by disrupting angiogenesis via targeting VEGFR2/VEGF and blocking VEGFR2/Erk/VEGF signaling. Cancer Lett. 2016, 382, 44-52. [CrossRef] [PubMed]

17. Rui, X.; Pan, H.F.; Shao, S.L.; Xu, X.M. Anti-tumor and anti-angiogenic effects of Fucoidan on prostate cancer: Possible JAK-STAT3 pathway. BMC Complement. Altern. Med. 2017, 17, 378. [CrossRef]

18. Dithmer, M.; Fuchs, S.; Shi, Y.; Schmidt, H.; Richert, E.; Roider, J.; Klettner, A. Fucoidan reduces secretion and expression of vascular endothelial growth factor in the retinal pigment epithelium and reduces angiogenesis in vitro. PLoS ONE 2014, 9, e89150. [CrossRef]

19. Ustyuzhanina, N.E.; Bilan, M.I.; Ushakova, N.A.; Usov, A.I.; Kiselevskiy, M.V.; Nifantiev, N.E. Fucoidans: Pro- or antiangiogenic agents? Glycobiology 2014, 24, 1265-1274. [CrossRef]

20. Anastyuk, S.D.; Shevchenko, N.M.; Ermakova, S.P.; Vishchuk, O.S.; Nazarenko, E.L.; Dmitrenok, P.S.; Zvyagintseva, T.N. Anticancer activity in vitro of a fucoidan from the brown alga Fucus evanescens and its low-molecular fragments, structurally characterized by tandem mass-spectrometry. Carbohydr. Polym. 2012, 87, 186-194. [CrossRef]

21. Kuznetsova, T.A.; Besednova, N.N.; Somova, L.M.; Plekhova, N.G. Fucoidan extracted from Fucus evanescens prevents endotoxin-induced damage in a mouse model of endotoxemia. Mar. Drugs 2014, 12, 886-898. [CrossRef]

22. Makarenkova, I.D.; Logunov, D.Y.; Tukhvatulin, A.I.; Semenova, I.B.; Besednova, N.N.; Zvyagintseva, T.N. Interactions between sulfated polysaccharides from sea brown algae and Toll-like receptors on HEK293 eukaryotic cells in vitro. Bull. Exp. Biol. Med. 2012, 154, 241-244. [CrossRef]

23. Dörschmann, P.; Bittkau, K.S.; Neupane, S.; Roider, J.; Alban, S.; Klettner, A. Effects of Fucoidans from Five Different Brown Algae on Oxidative Stress and VEGF Interference in Ocular Cells. Mar. Drugs 2019, 17, 258. [CrossRef]

24. Skriptsova, A.V.; Shevchenko, N.M.; Tarbeeva, D.V.; Zvyagintseva, T.N. Comparative study of polysaccharides from reproductive and sterile tissues of five brown seaweeds. Mar. Biotechnol. 2012, 14, 304-311. [CrossRef] 
25. Vishchuk, O.S.; Ermakova, S.P.; Zvyagintseva, T.N. The fucoidans from brown algae of Far-Eastern seas: Anti-tumor activity and structure-function relationship. Food Chem. 2013, 141, 1211-1217. [CrossRef]

26. Bilan, M.I.; Grachev, A.A.; Ustuzhanina, N.E.; Shashkov, A.S.; Nifantiev, N.E.; Usov, A.I. Structure of a fucoidan from the brown seaweed Fucus evanescens C.Ag. Carbohydr. Res. 2002, 337, 719-730. [CrossRef]

27. Cumashi, A.; Ushakova, N.A.; Preobrazhenskaya, M.E.; D’Incecco, A.; Piccoli, A.; Totani, L.; Tinari, N.; Morozevich, G.E.; Berman, A.E.; Bilan, M.I.; et al. Consorzio Interuniversitario Nazionale per la Bio-Oncologia, Italy. A comparative study of the anti-inflammatory, anticoagulant, antiangiogenic, and antiadhesive activities of nine different fucoidans from brown seaweeds. Glycobiology 2007, 17, 541-552. [CrossRef]

28. Schneider, T.; Ehrig, K.; Liewert, I.; Alban, S. Interference with the CXCL12/CXCR4 axis as potential antitumor strategy: Superiority of a sulfated galactofucan from the brown alga Saccharina latissima and fucoidan over heparins. Glycobiology 2015, 25, 812-824. [CrossRef]

29. Fitton, J.H.; Stringer, D.N.; Karpiniec, S.S. Therapies from Fucoidan: An Update. Mar. Drugs 2015, 13, 5920-5946. [CrossRef]

30. Sanjeewa, K.K.A.; Lee, J.S.; Kim, W.S.; Jeon, Y.J. The potential of brown-algae polysaccharides for the development of anticancer agents: An update on anticancer effects reported for fucoidan and laminaran. Carbohydr. Polym. 2017, 177, 451-459. [CrossRef]

31. Lahrsen, E.; Liewert, I.; Alban, S. Gradual degradation of fucoidan from Fucus vesiculosus and its effect on structure, antioxidant and antiproliferative activities. Carbohydr. Polym. 2018, 192, 208-216. [CrossRef]

32. Blasi, M.A.; Maresca, V.; Roccella, M.; Roccella, F.; Sansolini, T.; Grammatico, P.; Balestrazzi, E.; Picardo, M. Antioxidant pattern in uveal melanocytes and melanoma cell cultures. Investig. Ophthalmol. Vis. Sci. 1999, 40, 3012-3016.

33. Koinzer, S.; Reinecke, K.; Herdegen, T.; Roider, J.; Klettner, A. Oxidative Stress Induces Biphasic ERK1/2 Activation in the RPE with Distinct Effects on Cell Survival at Early and Late Activation. Curr. Eye Res. 2015, 40, 853-857. [CrossRef]

34. Kim, H.; Ahn, J.H.; Song, M.; Kim, D.W.; Lee, T.K.; Lee, J.C.; Kim, Y.M.; Kim, J.D.; Cho, J.H.; Hwang, I.K.; et al. Pretreated fucoidan confers neuroprotection against transient global cerebral ischemic injury in the gerbil hippocampal CA1 area via reducing of glial cell activation and oxidative stress. Biomed. Pharmacother. 2019, 109, 1718-1727. [CrossRef]

35. Strauss, O. The retinal pigment epithelium in visual function. Physiol. Rev. 2005, 85, 845-881. [CrossRef]

36. Bittkau, K.S.; Dörschmann, P.; Blümel, M.; Tasdemir, D.; Roider, J.; Klettner, A.; Alban, S. Comparison of the Effects of Fucoidans on the Cell Viability of Tumor and Non-Tumor Cell Lines. Mar. Drugs 2019, 17, 441. [CrossRef]

37. Handa, J.T.; Cano, M.; Wang, L.; Datta, S.; Liu, T. Lipids, oxidized lipids, oxidation-specific epitopes, and Age-related Macular Degeneration. Biochim. Biophys. Acta Mol. Cell Biol. Lipids 2017, 1862, 430-440. [CrossRef]

38. Van Leeuwen, E.M.; Emri, E.; Merle, B.M.J.; Colijn, J.M.; Kersten, E.; Cougnard-Gregoire, A.; Dammeier, S.; Meester-Smoor, M.; Pool, F.M.; de Jong, E.K.; et al. A new perspective on lipid research in age-related macular degeneration. Prog. Retin. Eye Res. 2018, 67, 56-86. [CrossRef]

39. Yokota, T.; Nomura, K.; Nagashima, M.; Kamimura, N. Fucoidan alleviates high-fat diet-induced dyslipidemia and atherosclerosis in ApoE(shl) mice deficient in apolipoprotein E expression. J. Nutr. Biochem. 2016, 32, 46-54. [CrossRef]

40. Park, M.K.; Jung, U.; Roh, C. Fucoidan from marine brown algae inhibits lipid accumulation. Mar. Drugs 2011, 9, 1359-1367. [CrossRef]

41. Copland, D.A.; Theodoropoulou, S.; Liu, J.; Dick, A.D. A Perspective of AMD Through the Eyes of Immunology. Investig. Ophthalmol. Vis. Sci. 2018, 59, AMD83-AMD92. [CrossRef]

42. Li, C.; Gao, Y.; Xing, Y.; Zhu, H.; Shen, J.; Tian, J. Fucoidan, a sulfated polysaccharide from brown algae, against myocardial ischemia-reperfusion injury in rats via regulating the inflammation response. Food Chem. Toxicol. 2011, 49, 2090-2095. [CrossRef]

43. Mariotti, F.; Tomé, D.; Mirand, P.P. Converting nitrogen into protein-beyond 6.25 and Jones' factors. Crit. Rev. Food Sci. Nutr. 2008, 48, 177-184. [CrossRef]

44. Albersheim, P.; Nevins, D.J.; English, P.D.; Karr, A. A method for the analysis of sugars in plant cell-wall polysaccharides by gas-liquid chromatography. Carbohydr. Res. 1967, 5, 340-345. [CrossRef] 
45. Blakeney, A.B.; Harris, P.J.; Henry, R.J.; Stone, B.A. A simple and rapid preparation of alditol acetates for monosaccharide analysis. Carbohydr. Res. 1983, 113, 291-299. [CrossRef]

46. Filisetti-Cozzi, T.M.; Carpita, N.C. Measurement of uronic acids without interference from neutral sugars. Anal. Biochem. 1991, 197, 157-162. [CrossRef]

47. Sánchez-Rangel, J.C.; Benavides, J.; Heredia, J.B.; Cisneros-Zevallos, L.; Jacobo-Velázquez, D.A. The Folin-Ciocalteu assay revisited. Improvement of its specificity for total phenolic content determination. Anal. Methods 2013, 5, 5990. [CrossRef]

48. Gerhäuser, C.; Klimo, K.; Heiss, E.; Neumann, I.; Gamal-Eldeen, A.; Knauft, J.; Frank, N. Mechanism-based in vitro screening of potential cancer chemopreventive agents. Mutat. Res. 2003, 523, 163-172. [CrossRef]

49. Groth, I.; Alban, S. Elastase inhibition assay with peptide substrates-An example for the limited comparability of in vitro results. Planta Med. 2008, 74, 852-858. [CrossRef]

50. Becker, M.; Franz, G.; Alban, S. Inhibition of PMN-elastase activity by semisynthetic glucan sulfates. Thromb. Haemost. 2003, 89, 915-925. [CrossRef]

51. Wiencke, A.K.; Kiilgaard, J.F.; Nicolini, J.; Bundgaard, M.; Röpke, C.; La Cour, M. Growth of cultured porcine retinal pigment epithelial cells. Acta Ophthalmol. Scand. 2003, 81, 170-176. [CrossRef]

52. Klettner, A.; Roider, J. Comparison of bevacizumab, ranibizumab, and pegaptanib in citro: Efficiency and possible additional pathways. Investig. Ophthalmol. Vis. Sci. 2008, 49, 4523-4527. [CrossRef]

53. Riss, T.L.; Moravec, R.A.; Niles, A.L.; Duellman, S.; Benink, H.A.; Worzella, T.J.; Minor, L. Assay Guidance Manual [Internet]; Eli Lilly \& Company and the National Center for Advancing Translational Sciences: Bethesda, MD, USA, 2004; 1 May 2013 [updated 1 July 2016]; Available online: https://www.ncbi.nlm.nih. gov/books/NBK144065/ (accessed on 12 September 2019).

54. Klettner, A.; Möhle, F.; Lucius, R.; Roider, J. Quantifying FITC-labeled latex beads opsonized with photoreceptor outer segment fragments: An easy and inexpensive method of investigating phagocytosis in retinal pigment epithelium cells. Ophthalmic Res. 2011, 46, 88-91. [CrossRef]

(C) 2019 by the authors. Licensee MDPI, Basel, Switzerland. This article is an open access article distributed under the terms and conditions of the Creative Commons Attribution (CC BY) license (http://creativecommons.org/licenses/by/4.0/). 